\title{
Clostridium difficile genotypes other than ribotype 078 that are prevalent among human, animal and environmental isolates
}

\author{
Sandra Janezic ${ }^{1}$, Matjaz Ocepek², Valerija Zidaric ${ }^{1}$ and Maja Rupnik ${ }^{1,3,4^{*}}$
}

\begin{abstract}
Background: Characterising the overlap of $C$. difficile genotypes in different reservoirs can improve our understanding of possible transmission routes of this pathogen. Most of the studies have focused on a comparison of the PCR ribotype 078 isolated from humans and animals. Here we describe for the first time a comparison of C. difficile genotypes isolated during longer time intervals from different sources including humans, animals and the non-hospital environment.

Results: Altogether 786 isolates from time interval 2008-2010 were grouped into 90 PCR ribotypes and eleven of them were shared among all host types and the environment. Ribotypes that were most common in humans were also present in water and different animals $(014 / 020,002,029)$. Interestingly, non-toxigenic isolates were very common in the environment (30.8\%) in comparison to humans (6.5\%) and animals (7.7\%). A high degree of similarity was observed for human and animal isolates with PFGE. In human isolates resistance to erithromycin, clindamycin and moxifloxacin was detected, while all animal isolates were susceptible to all antibiotics tested.

Conclusion: Our results show that many other types in addition to PCR Ribotype 078 are shared between humans and animals and that the most prevalent genotypes in humans have the ability to survive also in the environment and several animal hosts. The genetic relatedness observed with PFGE suggests that transmission of given genotype from one reservoir to the other is likely to occur.
\end{abstract}

\section{Background}

Intestinal diseases caused by Clostridium difficile, mainly after antibiotic treatment, ranges from mild self-limiting diarrhoea to life-threatening pseudomembranous colitis (PMC) and were until recently most commonly seen in hospitalized elderly patients [1]. However, the incidence of community-onset $C$. difficile infection has increased [2-4] and C. difficile has also emerged as a pathogen or commensal in different animals such as pigs, calves and chickens [5-7]. Studies on C. difficile in the environment are sparse and describe its presence in soil and water [8-11]. For both, environmental contamination and community-associated human infections, animals have been suggested as possible reservoir $[5,12,13]$.

The most prevalent PCR ribotypes differ between humans and food animals. In bovine and porcine hosts

\footnotetext{
* Correspondence: maja.rupnik@zzv-mb.si

${ }^{1}$ Institute of Public Health Maribor, Prvomajska 1, 2000 Maribor, Slovenia Full list of author information is available at the end of the article
}

PCR ribotype 078 (corresponding to NAP7 and NAP8 by PFGE) is most often detected [14-16]. In humans approximately 300 PCR ribotypes are recognized and the most prevalent in many European countries is PCR ribotype 014/020 (toxinotype 0) [17]. However, in both animals and humans, the distribution of ribotypes is different between countries and from setting to setting, although the heterogeneity is much lower in animals compared to humans. Two large pan-European studies have shown these geographic differences for humanassociated C. difficile $[17,18]$. Commonly identified PCR ribotypes for which only regional spreading is suggested are 106, the predominant strain in the UK, ribotype 053 in Austria and 018 which is predominant in Italy $[19,20]$. In the United States and Canada NAP1, corresponding to PCR ribotype 027 is one of the predominant strains in humans, and in Japan and Korea PCR ribotype 017/toxinotype VIII $(\mathrm{A}-\mathrm{B}+)$ strain is responsible for CDI outbreaks $[21,22]$. 
Most of the comparative studies on C. difficile genotypes in humans and food animals have focused on ribotype 078 strain comparisons [23-25]. In addition to being the most frequently isolated strain from pigs and calves in North America and the Netherlands [14-16] it is becoming prevalent in humans in hospitals $[17,26]$ and in the community [3]. It is also often the most prevalent ribotype isolated from food [13,27]. Some other currently important human ribotypes $(027,017)$ are also reported from animals, [5] but they seem to be less well established in animal hosts. There is currently no published report comparing a large number of strains isolated in the same geographic region from different sources, including humans, animals and the environment. This study makes such a comparison of $C$. difficile strains isolated from three of the possible main reservoirs in a single country to show that ribotypes other than 078 are shared between host types and the environment.

\section{Results and discussion}

\section{Distribution of PCR ribotypes in different hosts and the} environment

All 786 isolates that were isolated between 2008 and 2010 were grouped into 90 different PCR ribotypes; human isolates into 77 ribotypes, animal isolates into 23 ribotypes and the environmental isolates into 36 ribotypes (Figure 1, see also Additional file 1: Table S1). There was a considerable overlap between $C$. difficile ribotypes isolated from humans, animals and the environment. Eleven PCR ribotypes were common to all three reservoirs. Sixteen PCR ribotypes were shared only between humans and the environment and were not found in animals, and eight PCR ribotypes were common only to humans and animals. None of the PCR ribotypes identified was shared just between animals and the environment. These results agree in part with previous observations that most genotypes present in animals are also isolated from humans in the same region $[15,16,28]$. Only a single study compared environmental and human $C$. difficile isolates and also noticed an overlap as 17 of 23 PCR ribotypes were shared between human and environmental strains [9].

The distribution of the most common PCR ribotypes isolated from all three reservoirs in the time period from 2008 to 2010 is shown in Table 1 . Interestingly, $30.8 \%$ of the environmental isolates were non-toxigenic compared to only $6.5 \%$ of human and $7.7 \%$ of animal isolates $(\mathrm{P}<$ 0.0001; Fisher's exact test). When only toxigenic strains are compared, the two most prevalent PCR ribotypes shared between all three reservoirs were 014/020 and 002 accounting for $20.1 \%$ and $8.2 \%$ (humans), $24.0 \%$ and $23.1 \%$ (animals), and $19.8 \%$ and $6.2 \%$ (environment), respectively. Results for PCR ribotypes 014 and 020 are combined as these two ribotypes have very similar banding pattern which is sometime difficult to distinguish using classical agarose gel-based electrophoresis. Ribotypes 014/020 and 002 are also among the most prevalent ribotypes in Europe [17]. This suggests that ability to survive in different environments plays a role in successful distribution and a high prevalence of a given genotype.

As already mentioned, most publications dealing with comparisons of animal and human strains focus on porcine ribotype 078 strains and suggest that pig farms can be an important emerging source of human infection or colonization $[23,24]$. Our previous studies have shown that ribotype 078 can be completely absent in animals in a given country and that ribotypes other than PCR ribotype 078 (toxinotype $\mathrm{V}$ ) are prevalent in pigs and other farm animals in Slovenia [7,29,30]. PCR ribotype 078 (toxinotype V) has been found only in humans in Slovenia; of six isolates identified, five came from stool specimens and one from an infected wound. PCR ribotype 126 (toxinotype $\mathrm{V}$ and highly related to ribotype 078) has been found in humans ( 7 isolates) and rivers ( 1 isolate).

Current epidemic strain, PCR ribotype 027/toxinotypeIII/NAP1 was reported in domestic animals and their environment mostly in Canadian studies [16,31,32]. Our collection did not include any animal 027 strain. First human PCR ribotype 027 strain was identified only in 2010 and this type accounted for as little as $2.7 \%(16 / 601)$ of all human isolates (see Additional file 1: Table S1).

\section{Characterisation of most common PCR ribotypes found in animals and humans}

Due to the large number of isolates available $(n=1078)$ only a subset of representative strains from the most common PCR ribotypes found in humans and animals were further characterized with PFGE and antimicrobial susceptibility testing. Selected strains belonged to 7 different PCR ribotypes: 014/020/(toxinotype 0), 010/(nontoxigenic strain; tox-), SLO 055/(tox-), 023/(toxinotype IV), 029/(toxinotype 0), 002/(toxinotype 0) and 150/(toxinotype 0$)$. A single strain of PCR ribotype SLO 055 was included in the comparison as its PCR ribotyping profile is very similar to the profile of PCR ribotype 010 .

The majority of strains of a single PCR ribotype isolated from humans and animals grouped together with PFGE regardless of which restriction enzyme was used (SmaI or SacII). With SmaI groups were more coherent and in four toxigenic PCR ribotypes (002, 029, 014/020 and 023), human and animal isolates had indistinguishable banding pattern (groups 2-5 on the Figure 2). However, when restriction was performed with SacII, only one pig isolate had an identical banding pattern to the human one while other animal isolates differed from human isolates of the same ribotype but still belonged to the same pulsotype (defined by $80 \%$ and $85 \%$ similarity for SmaI and SacII, respectively). Within non-toxigenic group of strains (group 1 on the Figure 2) a human 


\section{Humans \\ $(n=77)$}

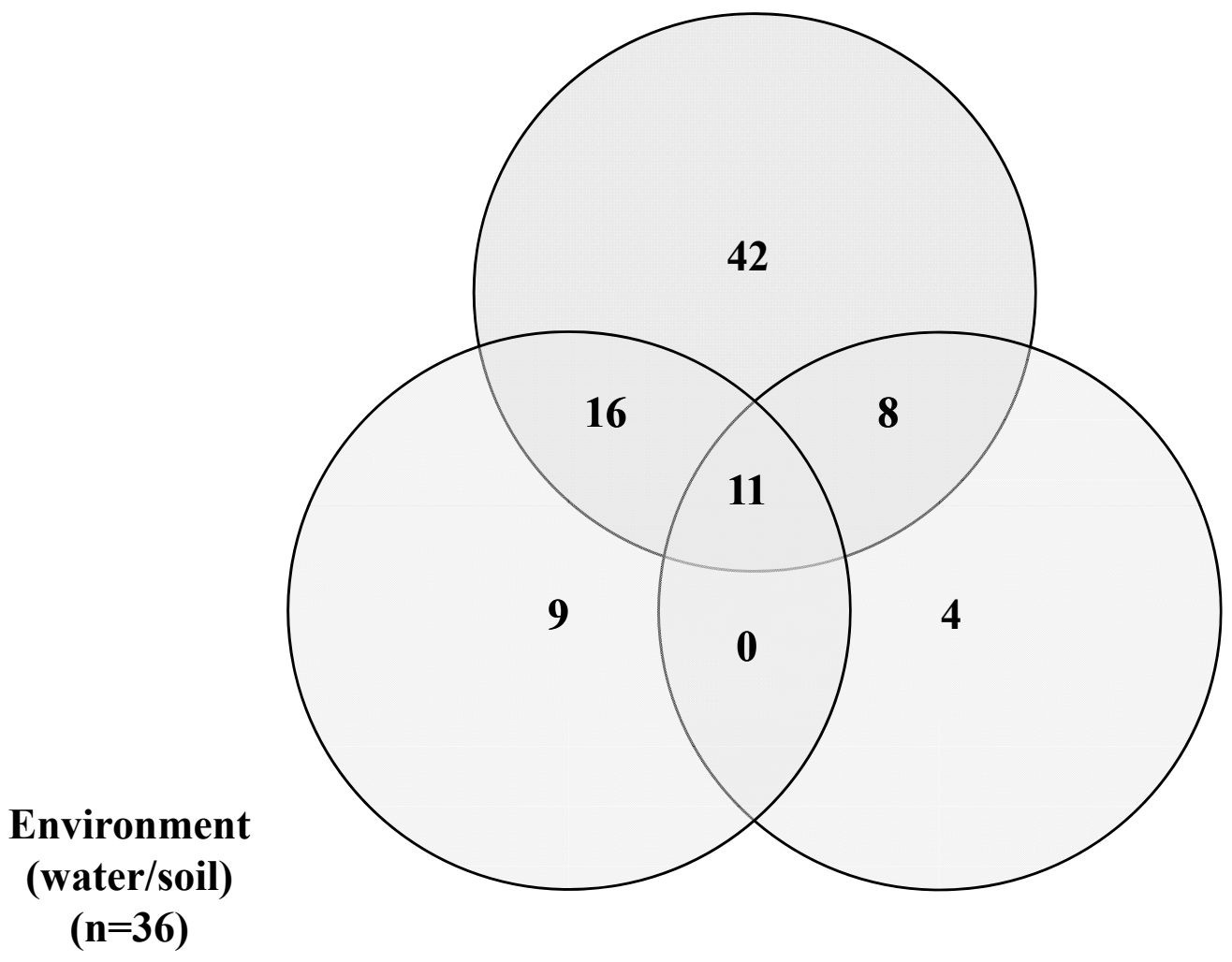

\section{Animals}

Figure 1 Comparison of distribution of ribotypes from different reservoirs

isolate of PCR ribotype SLO 055 (related to ribotype 010) had an identical banding pattern when restriction was performed with SmaI, though with SacII the human and the two animal isolates belonged to different pulsotypes. These results are in agreement with previous studies reporting human and food animal strains to be very closely related or indistinguishable using different typing methods. In the USA toxinotype V strains (PFGE type NAP7/NAP8 corresponding to ribotype 078) isolated from humans and pigs have been found to be indistinguishable with PFGE [25]. In more recent study by Koene et al. (2011), comparing human and animal isolates from the same geographic location and time period with the MLVA, authors confirmed previously observed relatedness between human and porcine ribotype 078 strains but in contrast to our PFGE results (group 4 on Figure 2) no genetic relatedness could be observed for human and animal isolates of ribotype 014 and 012 [24,33].

A great focus has been given on pigs as a source of human CDI. Poultry which can harbour a variety of human associated PCR ribotypes has been so far overlooked [7]. Two human and one poultry isolate of ribotype 023 (toxinotype IV, binary toxin positive) had indistinguishable banding pattern with $S m a$ I and belonged to the same pulsotype with SacII (group 5 on Figure 2). For companion animals (dogs and cats) has also been shown to harbour the same ribotypes as humans [15,33]. In our study, one dog and one cat isolate of PCR ribotype $014 / 020$ had identical banding pattern as the human isolates of the same PCR ribotype using SmaI restriction enzyme and belonged to the same pulsotype when SacII restriction patterns were compared (group 4 on Figure 2).

The genetic relatedness of human and animal isolates shown in this study suggests that not only ribotype 078 strains show zoonotic potential. Other ribotypes are shared between animals and humans as well, and that alongside porcine and cattle, poultry can also be an important link for human CDI. Whether and how often the transmission from animals to humans and/or vice versa occurs have yet to be determined.

Table 2 lists the range of MICs of the most common PCR ribotypes isolated from humans and animals for five out of six antibiotics tested. All isolates tested were fully 
Table 1 Most prevalent PCR ribotypes in humans, animals and the environment isolated between 2008 and 2010

\begin{tabular}{|c|c|c|c|}
\hline PCR ribotype/toxinotype & $\begin{array}{l}\text { Humans } \\
(n=601)\end{array}$ & $\begin{array}{l}\text { Animals } \\
(n=104)\end{array}$ & $\begin{array}{l}\text { Environment } \\
(n=81)\end{array}$ \\
\hline 014/020/0 or I & $121(20.1 \%)$ & 25 (24.0\%) & $16(19.8 \%)$ \\
\hline $002 / 0$ & $49(8.2 \%)$ & $24(23.1 \%)$ & $5(6.2 \%)$ \\
\hline 001/072/0, tox- or XXIV (CDT+1) & $42(7.0 \%)$ & $8(7.7 \%)$ & $2(2.5 \%)$ \\
\hline $012 / 0$ & $30(5.0 \%)$ & $/^{*}$ & $1(1.2 \%)$ \\
\hline 023/IV (CDT+) & $30(5.0 \%)$ & $/^{*}$ & $3(3.7 \%)$ \\
\hline $018 / 0$ & $27(4.5 \%)$ & / & $2(2.5 \%)$ \\
\hline $029 / 0$ & $24(4.0 \%)$ & $1(1.0 \%)$ & $3(3.7 \%)$ \\
\hline $150 / 0$ & $15(2.5 \%)$ & $9(8.7 \%)$ & l \\
\hline SLO 080/tox- & $1(0.2 \%)$ & $7(6.7 \%)$ & $1(1.2 \%)$ \\
\hline 045/ (CDT+) & $1(0.2 \%)$ & $5(4.8 \%)$ & / \\
\hline 010/tox- & $14(2.3 \%)$ & $/^{*}$ & $9(11.1 \%)$ \\
\hline SLO 057/tox- & $1(0.2 \%)$ & / & $4(4.9 \%)$ \\
\hline SLO 064/tox- & $2(0.3 \%)$ & / & $4(4.9 \%)$ \\
\hline $078 / \mathrm{N}$ & $6(1.0 \%)$ & l & / \\
\hline $126 / \mathrm{N}$ & $6(1.0 \%)$ & / & $1(1.2 \%)$ \\
\hline
\end{tabular}

$\mathrm{PCR}$ ribotypes marked with* have been found in animals only not between years 2008-10. ${ }^{\S}$ Results for PCR ribotypes 001 and 072 are combined in this table since they have a very similar banding pattern which is sometime difficult to distinguish using classical agarose gel-based electrophoresis. Ribotypes 078 and 126 are not among the most prevalent ribotypes and are added only for comparison. (CDT + ) - binary toxin positive

susceptible to rifampicin. With a few exceptions all strains within a single PCR ribotype had similar but not identical MICs for all antibiotics tested. Exceptions include high MICs to erythromycin (ERY), clindamycin (CLI) and moxifloxacin (MXF) (Table 2, Figure 2) for human ribotype 014/020 strains. Interestingly, all three human ribotype 010 strains (all non-toxigenic) had MICs $\geq 256 \mathrm{mg} / \mathrm{ml}$ for CLI and ERY (2 isolates), and CLI plus MXF (1 isolate). This multiple drug resistance in nontoxigenic strains could suggest that these strains might serve as reservoir of antibiotic resistance determinants. Strains resistant to the antibiotics tested were found only among human isolates. However, only for moxifloxacin, MICs for human isolates were more likely to be above the $\mathrm{MIC}_{50}$ of all isolates tested $(\mathrm{P}<0.05)($ Table 3$)$.

\section{Conclusions}

Ribotype 078 is not the only ribotype significantly shared between humans and animals. Here we show that all genotypes that are among most prevalent in (hospitalized) humans have a tendency to prevail also in animals and in the environment (river water) and that a better environmental survival might be part of their virulence spectrum. Human and animal isolates of the same PCR ribotype clustered together with PFGE and had mostly also similar MIC values for all antibiotics tested. This genetic relatedness suggests that transmission of given genotype from one reservoir to the other is likely to occur.

\section{Materials and methods \\ C. difficile isolates}

Isolates included in the comparison originated from humans, animals and the non-hospital environment and are part of the strain collection at the Institute of Public Health Maribor. Altogether 1078 isolates from Slovenia were available. Isolates from all three reservoirs were sampled from the overlapping geographical locations and time periods.

Human isolates $(n=690)$ were recovered by routine diagnostic laboratories throughout Slovenia and submitted to our laboratory for typing between 2006 and 2010. The isolates were from hospitalized patients and from patient from other institutions (less than $1 \%$ of all isolates), and were not submitted as a part of an outbreak investigation.

Environmental isolates were from river water $(\mathrm{n}=77)$ and soil $(\mathrm{n}=4)$, and were isolated between 2008 and 2010. River water isolates from 17 rivers throughout Slovenia were collected as a part of the national surveillance of surface waters. Soil isolates originated from the field near the poultry farm from which poultry samples were collected. The isolates were cultured as described elsewhere [11].

Animal isolates $(n=307)$ were from piglets $(n=138)$, calves $(n=6)$, a horse $(n=1)$, poultry and birds $(n=$ 150), and dogs and cats $(\mathrm{n}=12)$ isolated between 2006 and 2010. Piglet isolates (including symptomatic and asymptomatic animals) were from 9 pig farms located in different parts of Slovenia. Poultry isolates were from two big facility for laying hens and three smaller farms. Dog, cat and calf isolates were from different Slovenian households and farms. Stool samples or rectal swabs collected from these animals were processed as described elsewhere $[7,29]$. Due to the clustering (i.e. large number of isolates from the same animal farm), only 156 animal isolates (piglets $(\mathrm{n}=16)$, poultry and birds $(n=121)$, dogs and cats $(n=12)$, calves $(n=6)$ and a horse) were included in the final analysis (only a single strain isolated per sampling and per farm).

The final number of isolates included in the comparison of prevalence and distribution of PCR ribotypes was 786 (601 from human, 104 from animals and 81 from the environment) from the time period 2008-10, as for this time period environmental strains were available. For the PFGE and antimicrobial susceptibility testing of human and animal strains, 50 isolates from broader time interval (2006-2010) were selected.

\section{Molecular characterisation}

All isolates were characterised by toxinotyping and PCR ribotyping. Toxinotyping involved amplification and 


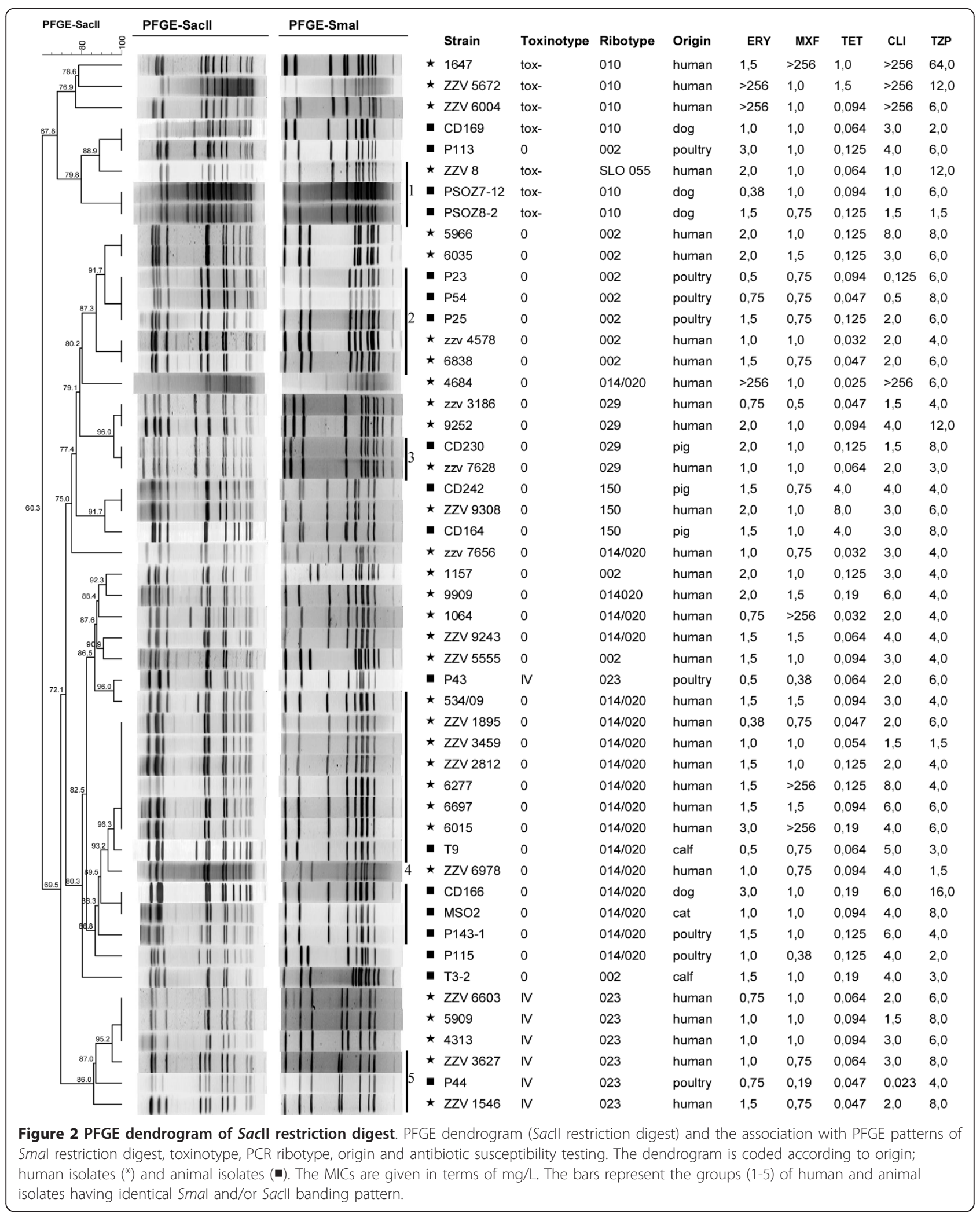


Table 2 MIC ranges of most common PCR ribotypes isolated from humans and animals

\begin{tabular}{clllll}
\hline PCR ribotype & $\begin{array}{l}\text { ERY } \\
(\mathbf{m g} / \mathbf{L})\end{array}$ & $\begin{array}{l}\text { MXF } \\
(\mathbf{m g} / \mathbf{L})\end{array}$ & $\begin{array}{l}\text { TET } \\
(\mathbf{m g} / \mathbf{L})\end{array}$ & $\begin{array}{l}\text { CLI } \\
(\mathbf{m g} / \mathbf{L})\end{array}$ & $\begin{array}{l}\text { TZP } \\
(\mathbf{m g} / \mathbf{L})\end{array}$ \\
\hline $002(n=11)$ & $0.5-3$ & $0.75-1.5$ & $0.032-0.19$ & $0.125-8$ & $3-8$ \\
\hline $023(n=7)$ & $0.5-1.5$ & $0.19-1$ & $0.047-0.094$ & $0.023-3$ & $4-8$ \\
\hline $029(n=4)$ & $0.75-2$ & $0.5-1$ & $0.047-0.125$ & $1.5-4$ & $3-12$ \\
\hline $014 / 020(n=18)$ & $0.38->256$ & $0.38->256$ & $0.025-0.19$ & $1.5->256$ & $1.5-16$ \\
\hline $010(n=6)$ & $0.38->256$ & $0.75->256$ & $0.064-1.5$ & $1->256$ & $1.5-64$ \\
\hline $150(n=3)$ & $1.5-2$ & $0.75-1$ & $4-8$ & $3-8$ & $4-8$ \\
\hline
\end{tabular}

ERY - erythromycin; CLI - clindamycin; TET- tetracycline; TZP - piperacillin/tazobactam; MXF - moxifloxacin; Ribotype SLO 055 ( $n=1$ ) is not included in this table, but is included in Table 3

subsequent restriction of PCR fragment A3 (part of $t c d \mathrm{~A}$ ) and $\mathrm{B} 1$ (part of $t c d \mathrm{~B}$ ). PaLoc negative strains were confirmed by amplification of a 115 bp-long insert with primers Lok1/Lok3 [34]. The binary toxin gene $(c d t \mathrm{~B})$ was detected as described previously [35].

PCR ribotyping was performed with the primers $16 \mathrm{~S}$ (5'-GTGCGGCTGGATCACCTCCT) and 23S (5'-CCCT GCACCCTTAATAACTTGACC) as described by Bidet et al. (1999) [36]. After amplification PCR products were concentrated to a final volume of $25 \mu \mathrm{l}$ by heating at $75^{\circ} \mathrm{C}$ for $45 \mathrm{~min}$ before electrophoresis in 3\% agarose gel (Bio-Rad, USA) in $1 \times$ TAE buffer for $5 \mathrm{~h}$ at $2.5 \mathrm{~V} / \mathrm{cm}$. BioNumerics software (Applied Maths, Belgium) version 6.10 was used to analyze the banding patterns. PCR ribotypes for which reference strains were available were designated by standard Cardiff nomenclature $(002,029 . . . ;$ 46 Cardiff type strains were available in our laboratory for comparisons) while others were designated by internal nomenclature (SLO and 3-digit code).

A total of $50 \mathrm{C}$. difficile isolates of the most prevalent PCR ribotypes found in humans and animals isolated between 2006 and 2010 were further analyzed with PFGE and antimicrobial susceptibility testing. Selection of the strains was made by randomly selecting human and animal strains isolated in the same time period and from the same geographic locations covering different Slovenian regions. These included 32 human isolates and 18 animal isolates from pigs $(n=3)$, poultry $(n=8)$, a cat $(n=1)$, calves $(n=2)$ and $\operatorname{dogs}(n=4)$.

\section{Pulsed field gel electrophoresis}

PFGE was performed as described elsewhere [37]. Genomic DNA was digested with $15 \mathrm{U}$ of SacII or SmaI (New England BioLabs, UK) overnight and Biometra PFGE System (Biometra, Germany) was used for electrophoresis. Dendrograms were constructed using BioNumerics software 6.10 (Applied Maths, Belgium) by the UPGMA clustering method, using the Dice coefficient with position tolerance and optimization of $1.10 \%$. Clusters with $\geq$ $80 \%$ (SmaI) or $\geq 85 \%$ (SacII) similarity were considered to be distinct pulsotypes.

\section{Antimicrobial susceptibility testing}

The same strains typed by PFGE were also tested for antibiotic resistance. Minimum inhibitory concentrations (MICs) of 6 antimicrobial agents; rifampicin (RIF), moxifloxacin (MXF), erythromycin (ERY), piperacilin/tazobactam (TZP), tetracycline (TET) and clindamycin CLI), were determined by the E-test method. An inoculum of McFarland 1.0 was swabbed on Brucella blood agar supplemented with haemin $(5 \mu \mathrm{g} / \mathrm{mL})$ and vitamin $K_{1}(1 \mu \mathrm{g} / \mathrm{ml})$. Plates were incubated for $48 \mathrm{~h}$ at $37^{\circ} \mathrm{C}$ in an anaerobic atmosphere. Bacteroides thetaiotaomicron ATCC 29741 was used as a quality control strain. Resistance was defined

Table $3 \mathrm{MIC}_{50 / 90}$ values of human and animal C.difficile isolates

\begin{tabular}{|c|c|c|c|c|c|c|}
\hline Host & & $\begin{array}{l}\text { ERY } \\
\text { (mg/L) }\end{array}$ & $\begin{array}{c}\mathrm{MXF} \\
(\mathrm{mg} / \mathrm{L})\end{array}$ & $\begin{array}{l}\text { TET } \\
(\mathrm{mg} / \mathrm{L})\end{array}$ & $\begin{array}{l}\text { CLI } \\
\text { (mg/L) }\end{array}$ & $\begin{array}{l}\text { TZP } \\
\text { (mg/L) }\end{array}$ \\
\hline \multirow[t]{3}{*}{ Humans $(n=32)$} & $\mathrm{MIC}_{50}$ & 1.5 & 1 & 0.094 & 3 & 6 \\
\hline & $\mathrm{MIC}_{90}$ & 3 & $>256$ & 0.19 & $>256$ & 12 \\
\hline & Range & $0.38->256$ & $0.50->256$ & $0.025-8$ & $1->256$ & $1.5-64$ \\
\hline \multirow[t]{3}{*}{ Animals $(n=18)$} & $\mathrm{MIC}_{50}$ & 1 & 0.75 & 0.125 & 3 & 6 \\
\hline & $\mathrm{MIC}_{90}$ & 2 & 1 & 0.19 & 5 & 8 \\
\hline & Range & $0.38-3$ & $0.19-1$ & $0.047-4$ & $0.023-6$ & $1.5-16$ \\
\hline \multirow[t]{3}{*}{ All $(n=50)$} & $\mathrm{MIC}_{50}$ & 1.5 & 1 & 0.094 & 3 & 6 \\
\hline & $\mathrm{MIC}_{90}$ & 3 & 1.5 & 0,19 & 8 & 8 \\
\hline & Range & $0.38->256$ & $0.19->256$ & $0.025-8$ & $0.023->256$ & $1.5-64$ \\
\hline
\end{tabular}


according the following breakpoints established by the CLSI guidelines: clindamycin (CLI) $\geq 8 \mathrm{mg} / \mathrm{l}$, tetracycline $(\mathrm{TET}) \geq 16 \mathrm{mg} / \mathrm{l}$, piperacillin/tazobactam $(\mathrm{TZP}) \geq$ $128 \mathrm{mg} / \mathrm{l}$, moxifloxacin (MXF) $\geq 8 \mathrm{mg} / \mathrm{l}$, erythromycin $(\mathrm{ERY}) \geq 8 \mathrm{mg} / \mathrm{l}$ and rifampicin (RIF) $\geq 4 \mathrm{mg} / \mathrm{l}[38,39]$. $\mathrm{MIC}_{50}$ and $\mathrm{MIC}_{90}$ were calculated for human and animal isolates. The frequencies at which the MICs for human isolates were above the $\mathrm{MIC}_{50}$ and $\mathrm{MIC}_{90}$ values for all isolates tested were compared with Fisher's exact $t$ test.

\section{Additional material}

Additional file 1: Table S1. PCR ribotypes identified in humans, animals and the environment between 2008 and 2010 in Slovenia.

\section{Acknowledgements}

The research leading to these results has received funding from European Communities $7^{\text {th }}$ Framework programme (FP7/2007-2011) under grant agreement No. 223585 (MR), and the Slovenian Research Agency (grant 1000-08-310144 and J4-2236). Part of this work was presented as a poster (P1408) at 20th European Congress of Clinical Microbiology and Infectious Diseases (ECCMID), 2010, Vienna, Austria.

\section{Author details}

${ }^{1}$ Institute of Public Health Maribor, Prvomajska 1, 2000 Maribor, Slovenia. ${ }^{2}$ Veterinary Faculty, University of Ljubljana, Gerbiceva 60, 1000 Ljubljana, Slovenia. ${ }^{3}$ Faculty of Medicine, University of Maribor, Slomskov trg 15, 2000 Maribor, Slovenia. ${ }^{4}$ Centre of Excellence, CIPKeBIP, Jamova 39, 1000 Ljubljana, Slovenia.

\section{Authors' contributions}

SJ carried out the molecular typing, performed data analysis, participated in the design of the study and helped to draft the manuscript. VZ carried out microbiological work and in part molecular typing of animal and environmental isolates. MO participated in microbiological work on animal isolates. MR participated in design of the study and coordination and helped to draft the manuscript. All authors have read and approved the final manuscript.

Received: 2 September 2011 Accepted: 27 March 2012

Published: 27 March 2012

\section{References}

1. Rupnik M, Wilcox MH, Gerding DN: Clostridium difficile infection: new developments in epidemiology and pathogenesis. Nat Rev Microbiol 2009, 7(7):526-536.

2. Chernak EJCC, Weltman A, McDonald LC, Wiggs L, Killgore G, Thompson A, LeMaile-Williams M, Tan E, Lewis FM: Severe Clostridium difficile-associated disease in population previously at low risk-four states, 2005. Morb Mortal Wkly Rep 2005, 54:1201-1205.

3. Limbago BM, Long CM, Thompson AD, Killgore GE, Hannett GE, Havill NL, Mickelson S, Lathrop S, Jones TF, Park MM, et al: Clostridium difficile strains from community-associated infections. J Clin Microbiol 2009, 47(9):3004-3007.

4. Wilcox MH, Mooney L, Bendall R, Settle CD, Fawley WN: A case-control study of community-associated Clostridium difficile infection. J Antimicrob Chemother 2008, 62(2):388-396.

5. Gould LH, Limbago B: Clostridium difficile in food and domestic animals: a new foodborne pathogen? Clin Infect Dis 2010, 51(5):577-582.

6. Weese JS, Reid-Smith RJ, Avery BP, Rousseau J: Detection and characterization of Clostridium difficile in retail chicken. Lett Appl Microbiol 2010, 50(4):362-365.
7. Zidaric V, Zemljic M, Janezic S, Kocuvan A, Rupnik M: High diversity of Clostridium difficile genotypes isolated from a single poultry farm producing replacement laying hens. Anaerobe 2008, 14(6):325-327.

8. al Saif N, Brazier JS: The distribution of Clostridium difficile in the environment of South Wales. J Med Microbiol 1996, 45(2):133-137.

9. Al-Saif NM, O'Neill GL, Magee JT, Brazier JS, Duerden BI: PCR-ribotyping and pyrolysis mass spectrometry fingerprinting of environmental and hospital isolates of Clostridium difficile. J Med Microbiol 1998, 47(2):117-121.

10. Baverud V, Gustafsson A, Franklin A, Aspan A, Gunnarsson A: Clostridium difficile: prevalence in horses and environment, and antimicrobial susceptibility. Equine Vet J 2003, 35(5):465-471.

11. Zidaric V, Beigot S, Lapajne S, Rupnik M: The occurrence and high diversity of Clostridium difficile genotypes in rivers. Anaerobe 2010, 16(4):371-375.

12. Rupnik M, Songer JG: Clostridium difficile Its Potential as a Source of Foodborne Disease. Adv Food Nutr Res 2010, 60:53-66.

13. Weese JS: Clostridium difficile in food-innocent bystander or serious threat? Clin Microbiol Infect 2010, 16(1):3-10.

14. Goorhuis A, Debast SB, van Leengoed LA, Harmanus C, Notermans DW, Bergwerff AA, Kuijper EJ: Clostridium difficile PCR ribotype 078: an emerging strain in humans and in pigs? J Clin Microbiol 2008, 46(3):1157, author reply 1158 .

15. Keel K, Brazier JS, Post KW, Weese S, Songer JG: Prevalence of PCR ribotypes among Clostridium difficile isolates from pigs, calves, and other species. Journal of Clinical Microbiology 2007, 45(6):1963-1964.

16. Rodriguez-Palacios A, Stampfli HR, Duffield T, Peregrine AS, TrotzWilliams LA, Arroyo LG, Brazier JS, Weese JS: Clostridium difficile PCR ribotypes in calves, Canada. Emerg Infect Dis 2006, 12(11):1730-1736.

17. Bauer MP, Notermans DW, van Benthem BH, Brazier JS, Wilcox MH, Rupnik M, Monnet DL, van Dissel JT, Kuijper EJ: Clostridium difficile infection in Europe: a hospital-based survey. Lancet 2011, 377(9759):63-73.

18. Barbut F, Mastrantonio P, Delmee M, Brazier J, Kuijper E, Poxton I: Prospective study of Clostridium difficile infections in Europe with phenotypic and genotypic characterisation of the isolates. Clin Microbiol Infect 2007, 13(11):1048-1057.

19. Indra A, Schmid D, Huhulescu S, Hell M, Gattringer R, Hasenberger $P$, Fiedler A, Wewalka G, Allerberger F: Characterization of clinical Clostridium difficile isolates by PCR ribotyping and detection of toxin genes in Austria, 2006-2007. J Med Microbiol 2008, 57(Pt 6):702-708.

20. Spigaglia P, Barbanti F, Dionisi AM, Mastrantonio P: Clostridium difficile isolates resistant to fluoroquinolones in Italy: emergence of PCR ribotype 018. J Clin Microbiol 2010, 48(8):2892-2896.

21. Kim $H_{\text {, Jeong }} \mathrm{SH}$, Roh $\mathrm{KH}$, Hong SG, Kim JW, Shin MG, Kim MN, Shin HB, Uh $Y$, Lee $H$, et al: Investigation of toxin gene diversity, molecular epidemiology, and antimicrobial resistance of Clostridium difficile isolated from 12 hospitals in South Korea. Korean J Lab Med 2010 30(5):491-497.

22. MacCannell DR, Louie TJ, Gregson DB, Laverdiere M, Labbe AC, Laing F, Henwick S: Molecular analysis of Clostridium difficile PCR ribotype 027 isolates from Eastern and Western Canada. J Clin Microbiol 2006, 44(6):2147-2152.

23. Bakker D, Corver J, Harmanus C, Goorhuis A, Keessen EC, Fawley WN, Wilcox MH, Kuijper EJ: Relatedness of human and animal Clostridium difficile PCR ribotype 078 isolates determined on the basis of multilocus variable-number tandem-repeat analysis and tetracycline resistance. $J$ Clin Microbiol 2010, 48(10):3744-3749.

24. Debast SB, van Leengoed LA, Goorhuis A, Harmanus C, Kuijper EJ, Bergwerff AA: Clostridium difficile PCR ribotype 078 toxinotype $V$ found in diarrhoeal pigs identical to isolates from affected humans. Environ Microbiol 2009, 11(2):505-511.

25. Jhung MA, Thompson AD, Killgore GE, Zukowski WE, Songer G, Warny M, Johnson S, Gerding DN, McDonald LC, Limbago BM: Toxinotype V Clostridium difficile in humans and food animals. Emerg Infect Dis 2008, 14(7):1039-1045.

26. Rupnik M, Widmer A, Zimmermann O, Eckert C, Barbut F: Clostridium difficile toxinotype $V$, ribotype 078 , in animals and humans. J Clin Microbiol 2008, 46(6):2146. 
27. Songer JG, Trinh HT, Killgore GE, Thompson AD, McDonald LC, Limbago BM: Clostridium difficile in retail meat products, USA, 2007. Emerg Infect Dis 2009, 15(5):819-821.

28. Simango C: Prevalence of Clostridium difficile in the environment in a rural comm. unity in Zimbabwe. Trans R Soc Trop Med Hyg 2006, 100(12):1146-1150

29. Avbersek J, Janezic S, Pate M, Rupnik M, Zidaric V, Logar K, Vengust M Zemljic M, Pirs T, Ocepek M: Diversity of Clostridium difficile in pigs and other animals in Slovenia. Anaerobe 2009, 15(6):252-255.

30. Pirs T, Ocepek M, Rupnik M: Isolation of Clostridium difficile from food animals in Slovenia. J Med Microbiol 2008, 57(Pt 6):790-792.

31. Weese JS, Finley R, Reid-Smith RR, Janecko N, Rousseau J: Evaluation of Clostridium difficile in dogs and the household environment. Epidemiol Infect 2010, 138(8):1100-1104.

32. Lefebvre SL, Weese JS: Contamination of pet therapy dogs with MRSA and Clostridium difficile. J Hosp Infect 2009, 72(3):268-269.

33. Koene MG, Mevius D, Wagenaar JA, Harmanus C, Hensgens MP, Meetsma AM, Putirulan FF, van Bergen MA, Kuijper EJ: Clostridium difficile in Dutch animals: their presence, characteristics and similarities with human isolates. Clin Microbiol Infect 2011, doi: 10.1111/j.14690691.2011.03651.x.

34. Rupnik M, Avesani V, Janc M, von Eichel-Streiber C, Delmee M: A novel toxinotyping scheme and correlation of toxinotypes with serogroups of Clostridium difficile isolates. J Clin Microbiol 1998, 36(8):2240-2247.

35. Stubbs S, Rupnik M, Gibert M, Brazier J, Duerden B, Popoff M: Production of actin-specific ADP-ribosyltransferase (binary toxin) by strains of Clostridium difficile. FEMS Microbiol Lett 2000, 186(2):307-312

36. Bidet $P$, Barbut $F$, Lalande V, Burghoffer B, Petit JC: Development of a new PCR-ribotyping method for Clostridium difficile based on ribosomal RNA gene sequencing. FEMS Microbiol Lett 1999, 175(2):261-266.

37. Janezic S, Rupnik M: Molecular typing methods for Clostridium difficile: pulsed-field gel electrophoresis and PCR ribotyping. Methods Mol Biol 2010, 646:55-65.

38. CLSI: Performance Standards for Antimicrobial Susceptibility Testing; TwentyFirst Informational Supplement. CLSI documnet M100-S21 Wayne, PA, USA: Clinical and Laboratory Standards Institute; 2011.

39. CLSI: Methods for Antimicrobial Susceptibility Testing of Anaerobic BacteriaSevnth Edition: CLSI document M11-A7 Wayne, PA, USA: Clinical and Laboratory Standards Institute; 2007.

doi:10.1186/1471-2180-12-48

Cite this article as: Janezic et al.: Clostridium difficile genotypes other than ribotype 078 that are prevalent among human, animal and environmental isolates. BMC Microbiology 2012 12:48.

\section{Submit your next manuscript to BioMed Central and take full advantage of:}

- Convenient online submission

- Thorough peer review

- No space constraints or color figure charges

- Immediate publication on acceptance

- Inclusion in PubMed, CAS, Scopus and Google Scholar

- Research which is freely available for redistribution

Submit your manuscript at www.biomedcentral.com/submit
Biomed Central 